\title{
Critical Discourse Analysis of Hoax on Primordial Issues in the Jakarta Gubernatorial Election 2017
}

\author{
Fawaz Syaefullah ${ }^{1}$, Aditya Perdana ${ }^{2}$ \\ \{fawazun18@gmail.com¹, adperd@gmail.com²\} \\ University of Indonesia, Indonesia ${ }^{1}$ \\ University of Indonesia, Indonesia ${ }^{2}$
}

\begin{abstract}
This article wants to describe the presence of primordialism in the hoax in the Jakarta Gubernatorial Election 2017. The abundant flow of information, massive campaigns, and high digital interaction turned out to be dealing with incorrect information, or better known as hoaxes. Primordial-themed Hoax threaten contestations based on rationality or compete with ideas, ideas, visions, missions, and programs. Besides that, hoax with a primordial theme tends to make voters shift, no longer become rational voters but sociological voters who choose based on religious or ethnic similarities. By using critical discourse analysis, this paper attempts to explain in a comprehensive manner the concept of the hoax with primordial themes in the Jakarta Gubernatorial Election 2017.
\end{abstract}

Keywords: Primordial, Hoax, Critical Discourse Analysis.

\section{Introduction}

Digital politics will be related to the massive use of the internet. This is at least because of the character of the internet that strongly supports digital politics [1]. First, multimedia characters. One factor that makes the internet a revolutionary media in the world is its success combining print media, audio media, and video media. Second, interactive characters. Interactive characters allow a user to create their own messages, publish content, or engage in online interactions. So communication that occurs two directions or even more than that, namely communication in various directions [2].

Digital politics characterized by the development of the internet allows information flows to spread and circulate very quickly. Regarding information, the internet allows everyone to access correct information and incorrect information. Incorrect information on the internet is often called Hoax. The Mastel Survey (2017) revealed that of 1,146 respondents, $44.3 \%$ of them received hoax news every day and $17.2 \%$ received more than once a day. Even the mainstream media that is relied upon as a media that can be trusted sometimes comes contaminated by the spread of hoaxes. The mainstream media is also a channel for hoax information/news dissemination, each at $1.20 \%$ (radio), 5\% (print) and $8.70 \%$ (television). Not only by mainstream media, but hoaxes are also now widely circulating in the public through online media [3]. The results of a study conducted by Mastel (2017) state that the most widely used channels in the distribution of hoax are websites, at 34.90\%, chat applications (Whatsapp, Line, Telegram) at $62.80 \%$, and through social media (Facebook, Twitter, Instagram and Path) which are the most used media, reaching $92.40 \%$. Meanwhile, the data presented by the Ministry of 
Communication and Information Technology says there are as many as 800 thousand sites in Indonesia which are indicated as hoax spreaders and utterances of hate [4].

The emergence of Hoax more and more at the time of the presidential election or the election took place. This can be seen during the Jakarta Gubernatorial Election 2017 At that time, hoax were widely circulating in the community [4]. There are more than 1,900 reports of alleged hoaxes that color the Jakarta Gubernatorial Election 2017 (according to Khairul Ashar, one of the founders of Turn Back Hoax - a digital initiative that allows users to report and reveal hoaxes circulating on social media). This means that indeed Hoax is quite massive in the implementation of the 2017 elections. This study intends to analyze the content of the primordial themed Hoax in the Jakarta Gubernatorial Election 2017.

\section{Research Method}

In a research, method is needed as a tool. This research was conducted using qualitative methodology. According to Sarantakos, methods are a tool for social researchers to choose the basic elements in their methodology, such as perceptions of reality, definitions of science, perceptions of human behavior, research goals [5]. Whereas the qualitative methodology aims to further dig deeper into an existing phenomenon. This study also uses Norman Fairclough's critical discourse analysis. Critical discourse analysis (often abbreviated as AWK) provides theories and methods that can be used to carry out empirical studies of the relationships between discourse and social and cultural development in different social domains. Norman Fairclough's model divides critical discourse analysis into three dimensions, namely the textual dimension, the dimensions of discourse, and the socio-cultural practical dimension. Furthermore, the problem examined is the problem that occurred at the time the research was carried out, in this case, the critical discourse analysis and the role of the primordial themed Hoax in the 2017 DKI Regional Election.

\section{Result and Discussion}

\subsection{The concept of Primordialism and Hoax}

Primordialism, which is a derivative of the politics identity, was first introduced by Edward Shills [6] who found various social bonds that were distinguished by personal, primordial, and sacred ties. These bonds still survive in the modern world. This approach assumes that social groups are characterized by regional, religious, cultural, linguistic, and social organizations that are objectively recognized as irrefutable. This primordial view has been criticized because it does not look at the ability of an individual to carry out various identities in various situations.

Furthermore, what is interesting is that primordialism is packaged in the form of hoaxes for the implementation of the Jakarta Gubernatorial Election 2017. However, it is important to clarify what is meant by "hoax." Researchers have acknowledged the difficulty in determining what, exactly, qualifies as a hoax. MacDougall [7] defines hoax as "deliberately made untruth made to disguise the truth". However, nowadays, the meaning of hoax is a little very specific. Hoax is news, information, false or false news. Hoax means false news and negative excess talking and arguing on the internet [8]. Lukmantoro, et al. [9] mentioned that it is important to distinguish between fake news and hoaxes. False news and hoaxes are defined as misleading 
information [10]. But they have significant differences. False news is misleading information that refers to actual facts, while hoax is information that is entirely manipulative which does not refer to any kind of fact.

\subsection{Hoax and Jakarta Gubernatorial Election 2017}

The implementation of the Jakarta Gubernatorial Election 2017 itself is very dynamic and quite attracts the attention of many parties. Interesting issues in the DKI Pilkada are marked by the strengthening of SARA sentiments on the internet. The issue of SARA is a theme that is easily found in the implementation of DKI Election. This in itself is triggered by events that appear in social reality. The issue of SARA began massively and became a discussion when the video spread of the candidate governor who was also incumbent, namely Ahok who was considered to harass Muslims through saying about Surat al-Maidah. Through digital media, it became viral and caused a massive upheaval of protests. The protest demanded that he be tried by Ahok called the movement 212, a movement of 2 December. After that, practically when the DKI Election enters the SARA issue campaign, it still exists and is quite massive on the internet.

This has led to the spotlight on the Jakarta Gubernatorial Election 2017 and the contention of campaign content on the internet is quite high. And in the end, there was a flow of information about the Jakarta Gubernatorial Election 2017 that flooded public spaces facilitated by the internet. In the context of the internet, the problem that arises is that not all information is correct. Fake information or Hoax is actually very much. Hoax that are very prevalent in the Jakarta Gubernatorial Election 2017 are an interesting issue to see and especially whether the success of managing information on the internet is faced with hoax or not. And what kind of hoax should be seen? Hoax are very diverse in content. For this reason, this paper focuses on people who have primordial content or things related to religious and ethnic groups. The Hoax classification, among others:

Table 1. Hoax on Primordial Issues

\begin{tabular}{|c|l|l|l|}
\hline No & \multicolumn{1}{|c|}{ Up date } & \multicolumn{1}{|c|}{ Tittle } & Content \\
\hline 1 & 3 January 2017 & $\begin{array}{l}\text { Ahok pilgrimage to the tomb of his adopted } \\
\text { mother wearing shoes }\end{array}$ & Religion issues \\
\hline 2 & 8 January 2017 & Ahok Morning Devotional Writing & Religion issues \\
\hline 3 & 17 Januari 2017 & $\begin{array}{l}\text { FPI Dissolves Free Treatment of PDI } \\
\text { Perjuangan DPP in Tambora }\end{array}$ & Religion issues \\
\hline 4 & 27 January 2017 & Pulo Mas Church Was Not Evicted & Religion issues \\
\hline 5 & 4 February 2017 & $\begin{array}{l}\text { Voters' KTPs are doubled for people who are } \\
\text { as ethnic as China }\end{array}$ & Ethnicity issues \\
\hline 6 & 9 February 2017 & $\begin{array}{l}\text { AA GYM: "It's better to choose corrupt } \\
\text { leaders but Muslims. Instead of a clean leader, } \\
\text { honest but KAFIR (Non-Muslim) " }\end{array}$ & Religion issues \\
\hline 7 & 16 February 2017 & $\begin{array}{l}\text { KPU's website was broken down by Chinese } \\
\text { hackers, so Ahok's voice rose }\end{array}$ & Ethnicity issues \\
\hline 8 & 16 February 2017 & $\begin{array}{l}\text { Sound Suction Machine from China Starts } \\
\text { Playing }\end{array}$ & Ethnicity issues \\
\hline 9 & 13 February 2017 & $\begin{array}{l}\text { If We Win the Church in Jakarta Must Be } \\
\text { Greater than Istiqla }\end{array}$ & Religion issues \\
\hline
\end{tabular}




\begin{tabular}{|c|l|l|l|}
\hline 10 & 13 February 2017 & $\begin{array}{l}\text { KH Maimoen Zubair Pray for the Bad for } \\
\text { Ahok }\end{array}$ & Religion issues \\
\hline 11 & 19 February & $\begin{array}{l}\text { Saudi Arabia Threatens Suspension of } \\
\text { Indonesian Hajj If Cases of Violence against } \\
\text { Religion Are Not Punished }\end{array}$ & Religion issues \\
\hline 12 & 18 February & $\begin{array}{l}\text { Ahok's wife: Indonesian Natives Become } \\
\text { People Just Stuck, Especially Becoming a } \\
\text { Leader! }\end{array}$ & Ethnicity issues \\
\hline 13 & 27 February 2017 & $\begin{array}{l}\text { PGI is ready to bless the Muslim supporters of } \\
\text { Ahok who are not managed by Muslims }\end{array}$ & Religion issues \\
\hline 14 & 6 March 2017 & $\begin{array}{l}\text { Ahok's claim shaking hands with King Salman } \\
\text { is a hoax }\end{array}$ & Religion issues \\
\hline 15 & 7 March 2017 & $\begin{array}{l}\text { King Salman's Salam Three finger pose in } \\
\text { Photo }\end{array}$ & Religion issues \\
\hline 16 & 30 March 2017 & $\begin{array}{l}\text { Political Contract Anies Baswedan To Lead } \\
\text { Jakarta With Islamic Syari'at Value }\end{array}$ & Religion issues \\
\hline 17 & 13 April 2017 & $\begin{array}{l}\text { Al Islam Fake Magazine "Realizing Syari'ah } \\
\text { for Jakarta" }\end{array}$ & Religion issues \\
\hline 18 & 17 April 2017 & $\begin{array}{l}\text { Circulating Letter of Inauguration of the } \\
\text { Jakarta Grand Mosque }\end{array}$ & Religion issues \\
\hline
\end{tabular}

Source: turnbackhoax.id

In the table above, it can be seen that primordial-themed hoaxes are very prevalent in the Jakarta Gubernatorial Election 2017. And hoax are increasingly becoming a problem considering Jakarta is a digital city characterized by high penetration of internet usage [11]. In addition, this is confirmed by the latest BPS survey on social media, among cities in Indonesia, Jakarta is the city with the most social media users, which is 3.5 million people [12]. Even this figure is very far compared to the 3 cities below Jakarta with the highest number of social media users, namely Surabaya 956 thousand people, Bekasi 677 thousand people, and Bandung 579 thousand people.

\subsection{Critical Discourse Analysis of Hoax in Jakarta Gubernatorial Election 2017}

\subsubsection{Hoax attacking Ahok}

The Ahok and Djarot pairs became partners who suffered a lot of hoax attacks in the Jakarta Gubernatorial Election 2017. The issue that attacks the couple also revolves around the issue of religion and ethnic issues. And this is proven on the hoax above. But it needs to be analyzed using critical discourse analysis regarding the hoax.

Picture 1. Hoax to choose Moslem leader 


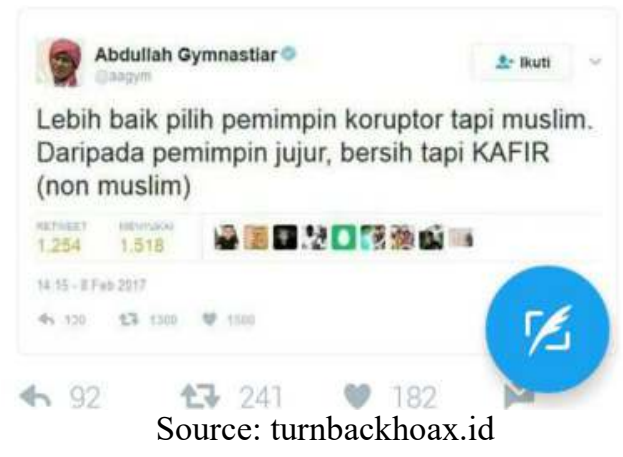

Picture 2. Ahok's wife is Racist
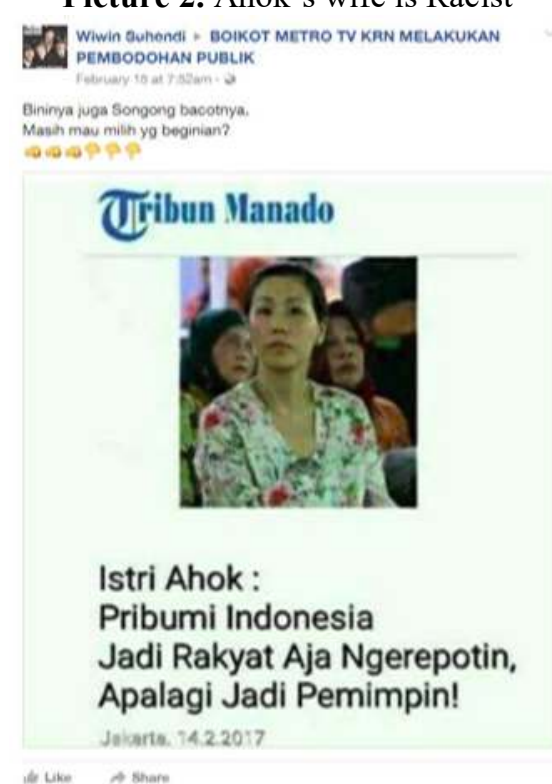

Source: turnbackhoax.id

\section{a. Textual Dimension}

Hoax on Ahok above textually strongly emphasizes that choosing Ahok is a matter that has consequences for faith. This means that in the grammar that wants to be highlighted: forbidden to choose leaders of different religions. By carrying a big name AA gym, textually the hoax maker wants to legitimize the hoax should be believed to be the truth. While in the second hoax, Ahok's wife was taken with the same purpose. And the hoax maker wants to emphasize that the two hoax are facts The theme taken in the hoax is also a framing that has a purpose. Hoax are the first themes of different religions that are highlighted and highlighted by the two themes of differences in ethnicity that are highlighted. The hoax maker clearly takes into account several possibilities and is clearly trying to make voters no longer categorized as rational voters, but sociological voters. This is reinforced by a very strong diction. The first Hoax call "infidel" and the second hoax calls "native". Of course, this strengthens the hoax has several agendas for voters. And most hoaxes that attack Ahok greatly elaborate on this side. 


\section{b. Language Awareness Dimension}

Analysis The production of text in the hoax is always not easy. It cannot be separated from hoax which is almost always anonymous and quickly spreads. Even with the two hoax above. The researcher conducted an analysis with the most reasonable possibilities of the hoax issued by whom. This is important because every hoax containing primordial has different interests. The logical primordial themed hoax that does not benefit a candidate is certainly made by another prospective team. However, in the context of the hoax where the wider community is involved, caution is needed in establishing such presumptions. Because it could be that affiliates or sympathizers of certain candidates produce for their own purposes. Even the people of Jakarta (or outside Jakarta because the internet cannot be partitioned by space and time) who are dissatisfied with the performance of incumbents become disappointed and make hoaxes.

Another thing related to the dimensions of discourse is the spread of text. According to Norman Fairclough, analysis of the spread of text emphasizes what media are used. In the context of hoax, the medium used is website and social media. Through these two mediums, it becomes easily spread and becomes other replicas. The more content is agreed upon and shows the position or alignment of the recipient of the hoax with the ideas or messages conveyed, the hoax will be more easily spread.

In the hoax, the first hoax uses twitter for the distribution process. With a distinctive Twitter character and accentuate writing rather than visuals, this hoax by carrying Aa Gym is almost believed to be a fact. It can be seen from the number of responses in the form of reply, retweet, and love. While the second hoax is spread using Facebook and emphasizes the visual aspect by cropping a story and editing it into the content that the hoax maker wants. The goal is clear, namely dropping the good name of Ahok's wife who has electoral correlations with Ahok.

Finally, the hoax is intended to be consumed by the recipient with the aim of harming Ahok. For this reason, the Hoax are spread mainly to floating masses in the hope of agreeing with the content and ultimately not choosing Ahok in the Jakarta Gubernatorial Election 2017.

\section{c. Socio-Cultural Dimensions}

The hoax was born in the previous condition Ahok was very favored to win. This hoax is an antithesis of Ahok's campaign itself. If in his campaign, Ahok tries to highlight aspects of ideas and ideas related to the vision and mission that will be carried out and some of his successes while leading Jakarta. So that Ahok and his team hoped that rationally the voters would vote for him. So, the hoax creates a condition that these facts are not important, when Ahok has a weakness in terms of religious and ethnic differences which are a minority in Jakarta. So that Hoax becomes a kind of response and an effort to prevent voters from becoming rational voters, but sociological voters.

\subsubsection{Hoax attacking Anies}

The Anies and Sandi pair also experienced a hoax attack on the Jakarta Gubernatorial Election 2017. The issue that attacks the couple is more about religious issues. And this is proven on the hoax above. But it needs to be analyzed using critical discourse analysis regarding the hoax.

Picture 3. Political Contracts Anies embodies Jakarta with Syari'at 


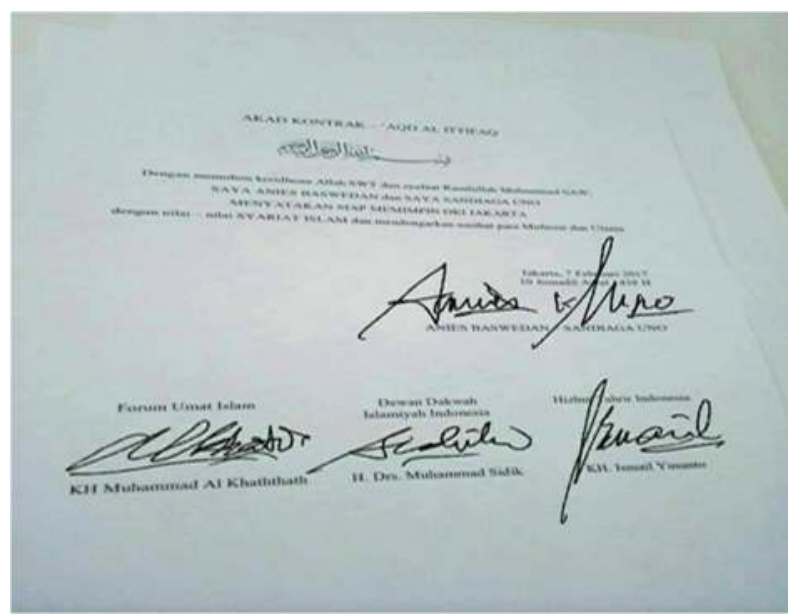

Source: turnbackhoax.id

Picture 4. Islam Syari'at for Jakarta with Anies

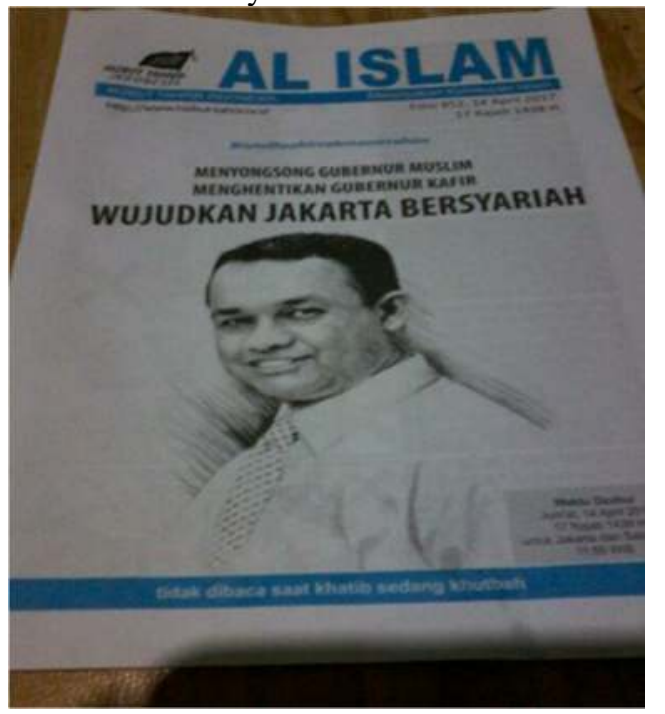

Source: turnbackhoax.id

\section{a. Textual Dimension}

Hoax towards the above Anies textually strongly emphasizes that choosing Anies is a threat to diversity. This means that in the grammar that wants to be highlighted: if Anies is elected, Jakarta is only for one religion, Islam. Hoaxes that attack Anies are very focused on these issues and try to make recipients testify to the content in a timely manner.

The theme taken in the hoax is also a framing that has the aim that diversity is being threatened. Both the first hoax and the hoaxes of the two themes regarding Jakarta which will belong to a single religion are very strongly described. As with hoax that attack Ahok, hoax makers also want voters not to be categorized as rational voters, but sociological voters. His 
hearing was very strong: Jakarta had the law. Of course, this strengthens the hoax has several agendas for voters and harms Anies.

\section{b. Language Awareness Dimension}

Analysis The production of text in the hoax of Anies by finding out who made it is the same as looking for a needle in a haystack. However, the author tries to analyze the logical possibilities not on the basis of who makes it, but for what the function of the meme is. As Anies tried to put forward the idea of Jakarta going forward together and the hoax tried to attack the idea. The hoax was born and produced to attack Anies' ideas. The first hoax is spread via WhatsApp. With its unique character, WhatsApp is able to spread the content to groups that are intensely communicating, such as office groups, family groups, and community groups. Hoax are indeed produced to bring down Anies. While in Hoax the second is distributed through bulletins claimed to be from Hizb ut-Tahrir Indonesia. However, from Hizb ut-Tahrir Indonesia through the media, it was denied and the turnbackhoax.id website described the photo as a hoax that was deliberately produced. Finally, the hoax is intended for consumption by the recipient with the aim of harming Anies. For this reason, the Hoax are spread mainly to floating masses in the hope of agreeing with the content and ultimately not choosing Anies in the Jakarta Gubernatorial Election 2017c. Cultural Socio-c. socio-cultural Dimensions.

Hoax was born in the condition of Anies' closeness with several Islamic groups and some of the Islamic identities that Anies displayed on several campaign occasions. Hoax tries to capture the socio-cultural situation to package it into the narrative that the maker wants: Anies wants to do Islamization with the city of Jakarta. So that the hoax clearly tries to highlight Anies as a symbol of diversity. So that the hoax maker clearly wants prospective voters to pay attention to this side, therefore the impact of the chancellor in electoral circles clearly chooses candidates who carry the idea of diversity, namely Ahok.

\section{Conclusion}

The Jakarta Gubernatorial Election 2017 becomes a complex picture regarding the presence of primordialism in the hoax. And this is increasingly becoming a problem considering Jakarta is a city with users and the highest internet penetration in Indonesia. Primordial themed Hoax also threaten contestations that are based on rationality or contest ideas, ideas, visions, missions and programs, into primordial contestations. And in the end, hoax is not only a trigger for polarization in elections but the achievement of overall election integrity and even lead to heavy homework after the election

In highlighting primordial-themed hoaxes, further research is needed using quantitative methodology. Especially looking at the influence of primordial themed hoax on voting behavior in DKI Jakarta. So that it becomes clearer, losing or winning a candidate is related or not with primordial themed hoaxes.

\section{References}

[1] A. F. \& M. J. S. Wood, Online Communication 2nd Edition. London: Lawrence ErlBaum Associates Publishers, 2005.

[2] R. Nasrullah, "Media Sosial: Perspektif Komunikasi, Budaya, dan Sosioteknologi," Bandung: Simbiosa Rekatama Media, 2015.

[3] Masyarakat Telekomunikasi Indonesia, "Hasil Survey Wabah HOAX Nasional 2017," Jakarta: 
Tim Mastel, 2017.

[4] C. Juditha, "Hoax Communication Interactivity in Social Media and Anticipation (Interaksi Komunikasi Hoax di Media Sosial serta Antisipasinya)," Pekommas, vol. 3, no. 1, 2018.

[5] S. Sarantakos, "Social Research Melbourne: Macmillan Education," 1993.

[6] E. Shills, Tradition. Chicago: The University Of Chicago Press, 1981.

[7] C. MacDougall, Hoaxes. New York: Dover Publications, 1958.

[8] A. Boese, The Museum of Hoaxes: A History of Outrageous Pranks and Deceptions. Plume, 2003.

[9] H. P. Santosa, N. Hasfi, and T. Lukmantoro, "Digital Media Unequality During the 2014th Indonesian Presidential Election," in E3S Web of Conferences, 2018, vol. 73, p. 14006.

[10] J. A. Braun and J. L. Eklund, "Fake News, Real Money: Ad Tech Platforms, Profit-Driven Hoaxes, and the Business of Journalism," Digit. Journal., vol. 7, no. 1, pp. 1-21, 2019.

[11] F. Andriadi, Partisipasi politik virtual: demokrasi netizen di Indonesia. RMBooks, 2017.

[12] Asosiasi Penyelenggara Jasa Internet Indonesia, Survey APJII: Penetrasi Internet di Indonesia Capai 143 Juta Jiwa. Jakarta: Tim APJII, 2018. 